\title{
Pembelajaran Kooperatif Tipe STAD untuk Meningkatkan Aktivitas dan Hasil Belajar Matematika dengan Alat Peraga Gelas Variabel bagi Siswa SMPN 3 Kayangan
}

\author{
Ahmad Maulidi \\ SMP Negeri 3 Kayangan, Kabupaten Lombok Utara - Provinsi NTB \\ *Corresponding Author. Email: ahmadmaulidi1981@gmail.com
}

\begin{abstract}
This study aims to improve student activity and learning outcomes on the subject matter of linear equations with one variable with the help of variable glass props through STAD Type Cooperative learning for students of SMPN 3 Kayangan, North Lombok Regency. This research method uses classroom action research with qualitative and quantitative approaches, which are carried out in 2 cycles. Each cycle consists of stages of implementation, giving action, observation, and reflection. The subjects of this study were students of class VII.2 SMPN 3 Kayangan, totaling 33 students. Data collection techniques used observation sheets and tests were then analyzed descriptively qualitatively and quantitatively. The results of this study indicate that the increase in student learning outcomes in the first cycle obtained mastery learning reached $54.55 \%$ with an average value of 64.45 . In the second cycle, the learning completeness was obtained by $66.7 \%$ with an average value of 66.6 . From the results of this study, it was concluded that the STAD Type Cooperative approach learning could increase the activity and learning outcomes of class VII.2 students of SMP Negeri 3 Kayangan, North Lombok.
\end{abstract}

Abstrak: Penelitian ini bertujuan untuk meningkatkan aktivitas dan hasil belajar siswa pada materi pokok persamaan linear satu variabel dengan bantuan alat peraga gelas variable melalui pembelajaran Kooperatif Tipe STAD bagi siswa SMPN 3 Kayangan Kabupaten Lombok Utara. Metode penelitian ini menggunakan penelitian tindakan kelas dengan pendekatan kualitatif dan kuantitatif, yang dilaksanakan dalam 2 siklus. Setiap siklus terdiri dari tahap pelaksanaan, pemberian tindakan, observasi, dan refleksi. Subjek penelitian ini adalah siswa kelas VII.2 SMPN 3 Kayangan yang berjumlah 33 siswa. Teknik pengumpulan data menggunakan lembar observasi dan tes selanjutnya dianalisis secara diskriptif kualitatif dan kuantitatif. Hasil penelitian ini menunjukkan bahwa peningkatan hasil belajar siswa pada siklus I diperoleh ketuntasan belajar mencapai $54,55 \%$ dengan nilai rata-rata 64,45. Pada siklus II diperoleh ketuntasan belajar sebesar 66,7\% dengan nilai rata-rata sebesar 66,6. Dari hasil penelitian ini disimpulkan bahwa pembelajaran pendekatan Kooperatif Tipe STAD dapat meningkatkan aktivitas dan hasil belajar siswa kelas VII.2 SMP Negeri 3 Kayangan Lombok Utara.

\section{Article History}

Received: 27-10-2021

Revised: 11-11-2021

Accepted: 23-12-2021

Published: 07-01-2022

Key Words:

Cooperative Learning,

STAD, Learning

Activities, Learning

Outcomes, Mathematics.

\section{Sejarah Artikel}

Diterima: 27-10-2021

Direvisi: 11-11-2021

Disetujui: 23-12-2021

Diterbitkan: 07-01-2022

\section{Kata Kunci:}

Pembelajaran Kooperatif, STAD, Aktivitas Belajar, Hasil Belajar, Matematika.

How to Cite: Maulidi, A. (2022). Pembelajaran Kooperatif Tipe STAD untuk Meningkatkan Aktivitas dan Hasil Belajar Matematika dengan Alat Peraga Gelas Variabel bagi Siswa SMPN 3 Kayangan. Jurnal Paedagogy, 9(1), 45-54. doi:https://doi.org/10.33394/jp.v9i1.4330

dol

https://doi.org/10.33394/jp.v9i1.4330

This is an open-access article under the CC-BY-SA License.

\section{Pendahuluan}

Kegiatan pembelajaran merupakan salah satu proses transfer ilmu pengetahuan dari seorang pendidik kepada peserta didik. Untuk menyampaikan proses transfer ilmu ini banyak strategi, teknik, metode dan model pembelajaran yang dapat dilakukan (Suarni et al., 2021). Salah satunya adalah model pengajaran langsung. Model pengajaran ini lebih menitikberatkan proses pembelajaran pada guru (teacher oriented). Guru Matematika 
bertindak mengontrol secara penuh materi pembelajaran serta metode penyampaiannya. Dalam KTSP disebutkan bahwa "Kurikulum dikembangkan berdasarkan prinsip bahwa peserta didik memiliki posisi sentral untuk mengembangkan potensinya..." (Muslich, 2007). Implikasinya, pembelajaran yang sebelumnya bersifat teacher oriented hendaknya diubah menjadi pembelajaran bersifat student oriented yang memberikan kesempatan pada siswa untuk aktif mengkonstruksi pengetahuannya sendiri. Dengan demikian, pemahaman konsep, kemampuan penalaran dan komunikasi, serta kemampuan pemecahan masalah siswa dapat ditingkatkan, yang nantinya akan berimbas pada peningkatan prestasi belajar Matematika siswa.

Berdasarkan dua landasan di atas sudah saatnya pembelajaran yang sifatnya teacher oriented harus diubah menjadi student oriented. Siswa diberikan kesempatan untuk mengkontruksi pemahaman mereka sendiri dan guru menjadi fasilitator dalam proses pembelajaran. Seperti yang dikemukakan J. Peaget dalam Rohani (2004) menegaskan, "seorang anak akan berpikir sepanjang ia berbuat. Tanpa berbuat anak tak berpikir. Agar ia berpikir sendiri (aktif) ia harus diberi kesempatan untuk berbuat sendiri". Jadi, seyogyanya proses membangun pemahaman tersebut dilakukan sendiri oleh siswa dan guru memantapkan saja (Muslich, 2007).

Pembelajaran di era sekarang membutuhkan strategi yang berbeda dengan pembelajaran di masa lalu. Pada masa sekarang, kemampuan berfikir siswa disesuaikan dengan perkembangan informasi dan teknologi. Kebutuhan berfikir untuk masa sekarang sangat dititikberatkan bagaimana siswa berfikir secara kritis dan lebih maju serta mampu menyederhanakan setiap permasalahan yang dihadapi. Kemampuan ini dikenal sebagai Keterampilan Berfikir Tingkat Tinggi (High Order Thinking Skills/HOTS). Pemerintah mengharapkan para siswa mencapai berbagai kompetensi dengan penerapan HOTS atau Keterampilan Bepikir Tingkat Tinggi. Kompetensi tersebut yaitu berpikir kritis (criticial thinking), kreatif dan inovasi (creative and innovative), kemampuan berkomunikasi (communication skill), kemampuan bekerja sama (collaboration), dan kepercayaan diri (confidence). Lima hal yang disampaikan pemerintah yang menjadi target karakter siswa tersebut pada sistem evaluasi, yaitu dalam UN dan juga merupakan kecakapan abad 21.

SMPN 3 Kayangan sebagai salah satu sekolah menengah pertama yang berstatus negeri di Kabupaten Lombok Utara, mencoba untuk menerapkan kebiasaan berfikir seperti ini di sekolah. Sebagai salah satu karakter yang harus dibiasakan di lingkungan sekolah, berfikir tingkat tinggi ini sangat membantu para siswa untuk dapat menganalisis permasalah yang diberikan guru dalam kegiatan pembelajaran di kelas. Diharapkan setelah karakter ini tertanam, maka semua permasalahan dapat dicari solusinya dengan jalan berfikir tingkat tinggi semacam ini.

Berdasarkan data hasil tes kompetensi para siswa untuk mata pelajaran Matematika di SMPN 3 Kayangan, baik dari ulangan harian, ulangan tengah semester, ulangan semester bahkan sampai ujian nasional, diperoleh tingkat kemampuan anak masih dalam kategori kurang. Dalam ulangan harian (pretest) sebelum pemberian materi menunjukkan hasil yang kurang memuaskan dimana nilai siswa masih bearada dibawah nilai rata-rata. Kurang dari $50 \%$ siswa yang berhasil mencapai nilai standar atau KKM yang ditetapkan yakni 65 . Demikian pula dengan hasil belajar pada tahun pelajaran sebelumnya, rata-rata ulangan harian siswa pada semester ganjil pada materi pokok Bilangan Bulat, Pecahan, Operasi hitung Aljabar, dan Persamaan Linear Satu Variabel masih menunjukkan hasil yang sama.

Salah satu faktor penyebabnya adalah lemahnya interaksi di dalam KBM baik antar siswa di kelas VII maupun antara siswa dengan kami selaku guru Matematika mereka. Siswa 
jarang berdiskusi dengan siswa lainnya dalam menghadapi masalah Matematika, dan hampir tidak berani mengajukan pertanyaan jika ada ketidakjelasan materi yang disampaikan guru. Kesulitan sebagian besar siswa di dalam memahami konsep-konsep matematika yang abstrak juga menjadi permasalahan klasik yang kami hadapi. Ketidakpahaman siswa akan konsep Matematika, membuat siswa kurang mampu mengekspresikan kemampuannya dalam komunikasi tertulis.

Matematika adalah ilmu yang bersifat abstrak. Salah satu materi yang masih kurang sekali penguasaanya adalah konsep Persamaan Linear Satu Variabel (PLSV). Materi ini merupakan materi yang diajarkan di kelas VII semester 1. Materi ini merupakan materi baru dan juga bersifat sangat abstrak bagi siswa. Siswa cenderung menuliskan semua hal yang dituliskan guru di papan tulis tanpa memahami makna yang terkandung dari simbol-simbol yang dituliskan terlebih dahulu.di dalam buku paket yang dimiliki oleh siswa, cara untuk menjelaskan dan mencontohkan persamaan linear satu variabel masih cukup membingungkan bagi siswa. Gambar-gambar yang ditampilkan di buku tersebut belum dapat sepenuhnya menggambarkan bagaimana penyelesaian persamaan linear satu variable dengan jelas. Siswa masih perlu membayangkan bagaimana gambar-gambar tersebut jika direalisasikan dalam bentuk yang kongkrit. Hal ini membuat siswa menjadi kebingungan. Akibatnya matematika menjadi sebuah momok bagi para siswa. Bagi mereka matematika adalah pelajaran yang paling sulit yang hanya berbicara simbol-simbol yang membingungkan. Hal ini berdampak pada rendahnya hasil belajar siswa.

Untuk memahami materi tersebut sangat dibutuhkan pendekatan-pendekatan khusus, salah satunya dengan menggunakan alat bantu pembelajaran yang berupa alat peraga. Alat peraga yang dipakai diusahakan sebisa mungkin dibuat sendiri oleh guru dan menggunakan bahan-bahan yang sering dilihat dan menarik bagi siswa. Hal ini dimaksudkan untuk lebih mempermudah siswa mengingat penggunaan alat peraga tersebut. Dengan menggunakan alat peraga di samping siswa dapat melihat dan mencoba secara langsung untuk mempraktekkan materi yang dijelaskan, hal ini juga dapat mengakibatkan adanya perubahan pandangan siswa terhadap matematika dari matematika yang menakutkan dan membosankan ke matematika yang menyenangkan sehingga keinginan untuk mempelajari matematika semakin besar.

Untuk memberikan pemerataan kesempatan belajar bagi siswa maka pembelajaran kooperatif dapat menjadi salah satu solusi. Melalui pembelajaran kooperatif, siswa dapat bekerjasama, saling membantu dan bertanggung jawab dalam aktivitas belajar (Burungge, 2020; Taqiya et. Al., 2021; Wirejati, 2019). Pembelajaran Kooperatif Tipe Student Teams Achievement Divisions (STAD) adalah satu tipe pembelajaran kooperatif yang paling sederhana, sehingga cocok bagi guru yang baru mulai menggunakan pembelajaran kooperatif. Walaupun sederhana, STAD memiliki ciri khas yakni adanya penghargaan kelompok yang merupakan gambaran perkembangan individual dari kinerja masing-masing anggota kelompok. Dengan adanya penghargaan kelompok, teknik ini diharapkan menarik minat serta memberikan semangat siswa dalam belajar dan berkompetisi secara positif sehingga diharapkan nilai matematika pada pokok bahasan ini bisa meningkat dan mencapai target ketuntasan secara individual dan klasikal (Israil, 2019; Yuliati, 2018; Nyoman Padmi, 2018). Adapun tujuan penelitian ini adalah untuk untuk meningkatkan aktivitas dan hasil belajar siswa pada materi pokok persamaan linear satu variabel dengan bantuan alat peraga gelas variable melalui pembelajaran Kooperatif Tipe STAD bagi siswa SMPN 3 Kayangan Kabupaten Lombok Utara. 


\section{Metode Penelitian}

Metode penelitian ini menggunakan penelitian tindakan kelas (PTK) dengan menggunakan model Kemmis \& Taggart (Arikunto, 2011). PTK merupkan salah satu upaya guru atau praktisi dalam bentuk berbagai kegiatan yang dilakukan untuk memperbaiki dan atau meningkatkan mutu pembelajaran di kelas. Penelitian ini dilaksanakan di SMP Negeri 3 Kayangan dengan subyek penelitiannya adalah siswa kelas VII 2 dengan jumlah siswa 33 orang siswa yang terdiri atas 17 orang siswa putra dan 16 orang siswa putri. Materi pokok dalam penelitian ini adalah Persamaan Linear Satu Variabel.

Penelitian ini dilaksanakan dalam 2 siklus yang disesuaikan dengan pembagian sub materi pokok. Masing-masing siklus terdiri dari lima tahap kegiatan yaitu tahap perencanaan, tahap pelaksanaan tindakan, tahap observasi, tahap evaluasi dan tahap refleksi. Masingmasing siklus terdiri atas dua kali pertemuan untuk kegiatan belajar mengajar dan satu kali pertemuan untuk evaluasi. Instrument penelitian ini menggunakan lembar observasi dan tes. Sedangkan teknik analisis datanya menggunakan analisis deskriptif kualitatif dan kuantitatif.

\section{Hasil Penelitian dan Pembahasan}

Pada penelitian ini, data tentang aktivitas belajar siswa dan kegiatan guru dalam proses belajar mengajar diperoleh dari lembar observasi sedangkan data tentang hasil belajar siswa diperoleh melalui tes yang dilakukan pada setiap siklus. Adapun hasil penelitian dalam setiap siklus adalah sebagai berikut :

\section{Deskripsi Siklus I}

Pada siklus I, proses belajar mengajar dilaksanakan dalam 3 kali pertemuan masingmasing dengan alokasi waktu 2 × 40 menit. Pertemuan pertama pada tanggal 2 Februari 2020, Pertemuan kedua pada tanggal 4 Februari 2020, dan untuk pelaksanaan evaluasi dilakukan pada tanggal 9 Februari 2020 dengan alokasi waktu 60 menit. Materi yang dipelajari pada pertemuan pertama adalah penjumlahan dan pengurangan bilangan bulat dengan menggunakan metode hutang bayar yang sudah diajarkan sebelumnya di tingkat Sekolah Dasar. Kegiatan pada siklus I terdiri atas 3 tahap antara lain:

\section{Tahap Perencanaan Tindakan}

Dalam tahap perencanaan dilakukan kegiatan sebagai berikut :

1) Menyusun RPP.

2) Mengidentifikasi kemampuan siswa sebagai bahan pertimbangan dalam membentuk kelompok diskusi.

3) Membuat alat peraga.

4) Menyiapkan lembar observasi, untuk melihat bagaimana kegiatan guru dan siswa selama proses belajar mengajar.

5) Menyiapkan Lembar Kerja Siswa (LKS).

6) Menyiapkan soal latihan untuk diskusi akhir STAD

7) Menyiapkan soal tes hasil belajar dan pedoman penskorannya.

\section{Tahap Pelaksanaan Tindakan}

Pada tahap ini, RPP siklus I akan diterapkan, serta dilakukan pengamatan sesuai dengan lembar observasi yang telah dipersiapkan. Secara garis besar tahap pelaksanaan tindakan pada siklus I dapat diuraikan sebagai berikut:

Pertemuan I (Menjelaskan tentang konsep persamaan linear satu variabel )

a) Tahap pendahuluan

b) Kegiatan Inti

c) Penutup 
Pertemuan II (menyelesaikan persamaan linear satu variabel dengan cara biasa)

a) Tahap pendahuluan

b) Kegiatan Inti

c) Penutup

Pertemuan III (Evaluasi Siklus 1)

Pada pertemuan ini, diadakan evaluasi untuk mengetahui sejauh mana tingkat pemahaman siswa mengenai cara menyelesaikan persamaan linear satu variabel berdasarkan penjelasan yang sudah disampaikan guru di depan kelas.

\section{Tahap Observasi}

Observasi kegiatan guru

Hasil observasi terhadap kegiatan guru pada siklus I diperoleh data sebagai berikut:

Tabel 1. Hasil Observasi Aktivitas Guru Siklus I

\begin{tabular}{|c|c|c|}
\hline Pertemuan Ke- & Skor Rata-Rata Aktivitas & Kategori \\
\hline 1 & 15 & Baik \\
\hline 2 & 17 & Sangat Baik \\
\hline 3 & 17 & Sangat Baik \\
\hline
\end{tabular}

Berdasarkan lembar observasi terlihat beberapa kekurangan pada kegiatan pembelajaran siklus I diantaranya: (1) Guru kurang memiliki ketegasan dalam memberikan peringatan kepada siswa yang tidak serius dalam diskusi. (2) Guru kurang membuka kesempatan atau menanyakan pendapat dari kelompok lain. (3) Guru masih canggung sehingga pemberian penghargaan terlupakan bagi kelompok yang presentasi.

Observasi Aktivitas Belajar Siswa

Berdasarkan hasil observasi terhadap aktivitas belajar siswa pada siklus I diperoleh data sebagai berikut:

Tabel 2. Hasil Observasi Aktivitas Belajar Siswa Siklus I

\begin{tabular}{|c|c|c|}
\hline Pertemuan Ke- & Skor Rata-Rata Aktivitas & Kategori \\
\hline 1 & 15 & Aktif \\
\hline 2 & 15 & Aktif \\
\hline 3 & 15 & Aktif \\
\hline
\end{tabular}

Dari tabel dapat terlihat bahwa pada siklus I aktivitas siswa tergolong cukup aktif. Dari hasil observasi terdapat beberapa kekurangan dalam proses pembelajaran diantaranya antara lain : (1) Siswa kurang mampu menjaga ketertiban dalam diskusi. (2) Siswa masih malu atau ragu dalam mempresentasikan hasil diskusi. (3) Siswa belum mau mencoba menyimpulkan materi yang sudah dibahas secara mandiri.

\section{Tahap Evaluasi}

Setelah proses pembelajaran, guru melakukan evaluasi untuk melihat sejauh mana siswa menyerap materi yang sudah diajarkan di kelas. Soal evaluasi terdiri dari atas 10 soal dengan alokasi waktu 60 menit. Jumlah siswa yang mengikuti evaluasi sebanyak 33 orang. Hasil yang dicapai pada evaluasi siklus I dapat dilihat dalam tabel berikut:

Tabel 3. Hasil Evaluasi Siklus I

\begin{tabular}{|l|c|}
\hline \multicolumn{1}{|c|}{ Kategori } & Nilai \\
\hline Nilai terendah & 54 \\
\hline Nilai tertinggi & 78 \\
\hline Skor rata-rata kelas & 64,45 \\
\hline Ketuntasan & $54,55 \%$ \\
\hline
\end{tabular}




\section{Tahap Refleksi}

Pada siklus I jumlah skor aktivitas belajar siswa yang diperoleh sebesar 15 yang sudah tergolong aktif, sedangkan rata-rata nilai hasil belajar siswa 64,45. Dengan melihat indikator kerja yang telah ditentukan, menyatakan bahwa aktivitas belajar siswa pada sikus I sudah tercapai yakni aktivitas belajar siswa sudah tergolong aktif, namun ada beberapahal yang perlu diperbaiki dan ditingkatkan uantuk siklus II. Berdasarkan hasil observasi dan hasil evaluasi belajar siswa pada pertemuan I dan pertemuan II pada siklus I terdapat beberapa kekurangan dalam pelaksanaan kegiatan belajar mengajar. Berikut ini adalah perbaikanperbaikan yang akan dilakukan diantaranya antara lain pada : Kemampuan Guru dalam mengelola kelas harus ditingkatkan. Sebab beberapa anak masih ada yang melalukan aktivitas-aktivitas di luar kegiatan pembelajaran. Beberapa kelompok masih malu dan enggan bertanya diatasi dengan terus memberikan motivasi agar memiliki keberanian baik dalam bertanya maupun mengeluarkan pendapat. Memperhatikan alokasi waktu yang sudah ditentukan. Pada siklus I salah satu hambatan adalah guru kurang bisa mengatur kegiatan presentasi, sehingga banyak waktu yang habis pada saat presentasi siswa. Selanjutnya memberikan stimulus kepada siswa dalam hal menggunakan alat peraga atau mengisi LKS. Sebab pembelajaran ini masih sangat baru bagi siswa sehingga mereka terlihat masih canggung.

\section{Deskripsi Siklus II}

Pada siklus II, proses belajar mengajar dilaksanakan dalam 3 kali pertemuan masingmasing dengan alokasi waktu $2 \times 40$ menit. Pertemuan pertama pada tanggal 12 Februari 2020, Pertemuan kedua pada tanggal 17 Februari 2020, pelaksanaan evaluasi dilakukan pada tanggal 19 Februari 2020 dengan alokasi waktu 60 menit. Materi yang dipelajari pada siklus kedua adalah penyelesaian persamaan linear satu variable dengan menggunakan alat peraga gelas variabel.

\section{Tahap Perencanaan Tindakan}

Dalam tahap perencanaan dilakukan kegiatan sebagai berikut :

1) Menyusun RPP.

2) Membuat alat peraga.

3) Menyiapkan lembar observasi, untuk melihat bagaimana kegiatan guru dan siswa selama proses belajar mengajar.

4) Menyiapkan Lembar Kerja Siswa (LKS).

5) Menyiapkan soal latihan untuk diskusi akhir STAD

6) Menyiapkan soal tes hasil belajar dan pedoman penskorannya.

\section{Tahap Pelaksanaan Tindakan}

Pada tahap ini, RPP siklus II akan diterapkan, serta dilakukan pengamatan sesuai dengan lembar observasi yang telah dipersiapkan. Secara garis besar tahap pelaksanaan tindakan pada siklus II dapat diuraikan sebagai berikut:

Pertemuan I (Pengenalan Alat Peraga Gelas Variabel)

a). Tahap pendahuluan

- Menyampaikan tujuan pembelajaran,

- Mengingatkan materi yang telah dipelajari pada siklus I tentang persamaan linear satu variabel tanpa menggunakan bantuan alat peraga

- Menjelaskan bagaimana cara menggunakan alat peraga gelas variabel.

b) Kegiatan Inti 
Guru memberikan stimulus dan gambaran umum bagaimana persamaan linear satu variabel dan mendemonstrasikan langkah- langkahnya menggunakan alat peraga gelas variabel.

c) Penutup

- Guru menyampaikan kesimpulan akhir untuk materi hari ini yang berasal dari kesepakatan bersama dari guru dan siswa,

- Menginformasikan kepada siswa untuk mempelajari materi yang akan dipelajari dan halhal terkait pada pertemuan berikutnya.

Pertemuan II (Menjelaskan cara menyelesaikan persamaan linear satu variable dengan alat peraga)

a) Tahap pendahuluan

- Menyampaikan tujuan pembelajaran,

- Mengingatkan materi yang telah dipelajari sebelumnya tentang persamaan linear satu variabel.

- Mengecek kembali alat peraga yang dibawa siswa.

b) Kegiatan Inti

Guru memberikan stimulus dan penjelasan mengenai materi persamaan linear satu variabel dan mendemonstasikan bagaimana penggunaan gelas variabel untuk menyelesaikan persamaan linear satu variabel.

c) Penutup

- Guru menyampaikan kesimpulan akhir untuk materi hari ini yang berasal dari kesepakatan bersama dari guru dan siswa,

- Menginformasikan kepada siswa untuk mempelajari materi yang akan dipelajari dan halhal terkait pada pertemuan berikutnya.

\section{Tahap Observasi}

Observasi kegiatan guru

Hasil observasi terhadap kegiatan guru pada siklus II diperoleh data sebagai berikut:

Tabel 4. Hasil Observasi Aktivitas Guru Siklus II

\begin{tabular}{|l|l|l|}
\hline Pertemuan Ke- & Skor Rata-Rata Aktivitas & Kategori \\
\hline 1 & 19 & Sangat Baik \\
\hline 2 & 19 & Sangat Baik \\
\hline 3 & 20 & Sangat Baik \\
\hline
\end{tabular}

Observasi Aktivitas Belajar Siswa

Tabel 5. Hasil Observasi Aktivitas Belajar Siswa Siklus II

\begin{tabular}{|c|c|c|}
\hline Pertemuan Ke- & Skor Rata-Rata Aktivitas & Kategori \\
\hline 1 & 17 & Sangat Aktif \\
\hline 2 & 18 & Sangat Aktif \\
\hline 3 & 18 & Sangat Aktif \\
\hline
\end{tabular}

Dari tabel dapat terlihat bahwa pada siklus II aktivitas siswa tergolong aktif. Dari hasil observasi terlihat bahwa pada pertemuan I dan II aktivitas belajar siswa sudah tergolong sangat aktif. Hal ini menunjukkan peningkatan dari siklus sebelumnya yang berkategori aktif. Mengingat indikator keberhasilan adalah minimal berkategori aktif maka dapat dikatakan penelitian ini berhasil dalam meningkatkan aktivitas belajar siswa. 


\section{Tahap Evaluasi}

Evaluasi pada siklus II dilakukan dengan memberikan tes dalam bentuk essay sebanyak 10 soal dengan alokasi waktu 60 menit. Jumlah siswa yang mengikuti evaluasi adalah 26 orang. Hasil yang dicapai pada evaluasi siklus II dapat dilihat dalam tabel berikut :

Tabel 6. Hasil Evaluasi Siklus II

\begin{tabular}{|l|c|}
\hline \multicolumn{1}{|c|}{ Kategori } & Nilai \\
\hline Nilai terendah & 63 \\
\hline Nilai tertinggi & 80 \\
\hline Skor rata-rata kelas & 66,6 \\
\hline Ketuntasan & $66,7 \%$ \\
\hline
\end{tabular}

Dalam penelitian tindakan kelas ini, guru menerapkan penggunaan alat peraga melalui pembelajaran kooperatif tipe STAD untuk meningkatkan aktivitas dan prestasi belajar siswa pada pokok bahasan operasi penjumlahan dan pengurangan bilangan bulat. Pembelajaran diawali dengan penyajian tujuan pembelajaran, memberikan apersepsi, penemuan konsep melalui kegiatan manipulasi alat peraga dan demonstrasi dengan bimbingan guru melalui LKS, pemantapan dan penerapan konsep melalui latihan soal-soal, dan pada akhirnya membuat kesimpulan.

Kegiatan penelitian ini dilaksanakan dalam 2 siklus yang masing-masing siklus terdiri dari 3 pertemuan dimana 2 pertemuan diantaranya merupakan proses pembelajaran dan 1 pertemuan adalah kegiatan evaluasi untuk mengetahui sejauh mana siswa menyerap materi yang sudah dipelajari bersama. Namun penelitian ini dihentikan pada siklus ke II, sebab indikator-indikator keberhasilan sudah tercapai. Berdasarkan lembar observsi aktivitas siswa, rata-rata skor aktivitas belajar siswa pada siklus I adalah 15 , yang tergolong aktif. Selain itu juga diperoleh rata-rata nilai hasil belajar siswa adalah 64,45 dengan demikian ketuntasan belajar siswa pada siklus ini sudah tercapai.

Pelaksanaan pembelajaran siklus II dilaksanakan dengan melakukan perbaikanperbaikan pada kekurangan dalam siklus I, dengan lebih memotivasi siswa dalam pembelajaran, lebih memaksimalkan kerjasama kelompok dengan memberi himbauan kepada siswa untuk selalu bekerjasama dalam megerjakan LKS, membimbing siswa dalam membuat kesimpulan materi. Hasil pembelajaran siklus II lebih baik jika dibandingkan dengan hasil pembelajaran siklus I. Pada siklus II, skor aktivitas belajar siswa yang diperoleh sebesar 18 yang tergolong aktif, sedangkan rata-rata nilai hasil belajar siswa yang diperoleh adalah 66,6.

Peningkatan ini terjadi karena pada saat diskusi berlangsung, siswa aktif dalam mengerjakan LKS, mendayagunakan alat peraga serta kerjasama antara masing-masing anggota kelompok sudah terlihat. Siswa sudah aktif menemukan, merumuskan maupun memecahkan sendiri konsep yang ada dalam LKS. Pada Siklus II indikator kerja juga sudah terpenuhi dan terjadi peningkatan-peningkatan, dimana aktivitas belajar siswa meningkat dari aktif ke sangat aktif, dan hasil belajar siswa pun mengalami peningkatan sehingga mencapai kriteria ketuntasan klasikal di atas 65\%. Mengingat sudah tercapainya indikator keberhasilan baik di siklus I maupun II, peneliti memutuskan menghentikan penelitian. Dengan demikian dapat disimpulkan bahwa dengan penggunaan alat peraga Gelas Variabel melalui pembelajaran kooperatif tipe STAD dapat meningkatkan aktivitas dan hasil belajar siswa kelas VII.2 SMPN 3 Kayangan pada pokok bahasan persamaan linear satu variabel. Adapun penelitian ini sejalan dengan hasil penelitian Yuliati (2018), Israil (2019), dam Taqiya et al. (2021) yang menjelaskan bahwa pembelajaran dengan model pembelajaran kooperatif tipe STAD dapat meningkatkan aktivitas dan hasil belajar. Melalui pembelajaran kooperatif, 
siswa dapat bekerjasama, saling membantu dan bertanggung jawab dalam aktivitas belajar (Burungge, 2020; Taqiya et. Al., 2021; Wirejati, 2019).

\section{Kesimpulan}

Berdasarkan hasil penelitian yang telah dilaksanakan, dapat disimpulkan bahwa peningkatan hasil belajar siswa pada siklus I diperoleh ketuntasan belajar mencapai 54,55\% dengan nilai rata-rata 64,45 . Pada siklus II diperoleh ketuntasan belajar sebesar $66,7 \%$ dengan nilai ratarata sebesar 66,6. Dari hasil penelitian ini disimpulkan bahwa pembelajaran pendekatan Kooperatif Tipe STAD dapat meningkatkan aktivitas dan hasil belajar siswa kelas VII.2 SMP Negeri 3 Kayangan Lombok Utara.

\section{Saran}

Adapun saran-saran yang dapat dikemukakan berdasarkan hasil penelitian ini antara lain adalah; (1) Siswa diharapkan dapat lebih aktif dan termotivasi untuk membangun pemahaman konsepnya secara mandiri melalui kerjasama kelompok. (2) Guru perlu memanfaatkan penggunaan media pembelajaran dengan kasus-kasus kontekstual untuk meningkatkan motivasi, aktivitas dan hasil belajar siswa secara maksimal. (3) Kepada pihak sekolah diharapkan dapat mengembangkan dan mengkaji lebih jauh Penggunaan Alat Peraga Gelas Variabel maupun pembelajaran kooperatif khususnya STAD dalam pembelajaran untuk mendukung sistem pembelajaran yang telah ada.

\section{Daftar Pustaka}

Arikunto, Suharsimi. (2011). Prosedur Penelitian: Suatu Pendekatan Praktik. Edisi Revisi VII. Jakarta: PT. Rineka Cipta

Depdiknas. (2004). Teori-Teori Balajar Matematika. Jakarta: Departemen Pendidikan Nasional.

Estianingsih, Elly. (1994). Penggunaan Alat Peraga Dalam Pengajaran Matematika SD. Yogyakarta: PPPG.

Burengge, S. (2020). Penerapan Model Pembelajaran Kooperatif Tipe STAD dengan Pendekatan Kontekstual bagi Siswa SDN 7 Tentena Sulawesi Tengah. Jurnal Paedagogy, 7(4), 275-280. doi:https://doi.org/10.33394/jp.v7i4.2832

Israil, I. (2019). Implementasi Model Pembelajaran Cooperative Learning Tipe STAD untuk Meningkatkan Motivasi Belajar Siswa dalam Pembelajaran IPA di SMP Negeri 1 Kayangan. Jurnal Kependidikan: Jurnal Hasil Penelitian dan Kajian Kepustakaan di Bidang Pendidikan, Pengajaran dan Pembelajaran, 5(2), 117-123. doi:https://doi.org/10.33394/jk.v5i2.1807

Iswadi, Djoko. (2003).'Pengembangan Media/ Alat Peraga Pembelajaran Matematika di SLTP”. Makalah. Tidak dipublikasikan.

Muslich, Masnur. (2007) . KTSP Pembelajaran Berbasis Kompetensi dan Kontekstual. Jakarta: PT Bumi Angkasa.

Nyoman Padmi, I. (2018). Peningkatan Aktivitas Pembelajaran Pendidikan Kewarganegaraan Materi Perlindungan dan Penegakan Hukum dengan Metode Kooperatif Tipe STAD Pada Siswa Kelas XII IPS 2 di SMAN 3 Mataram. Jurnal Kependidikan: Jurnal Hasil Penelitian dan Kajian Kepustakaan di Bidang Pendidikan, Pengajaran dan Pembelajaran, 4(2), 151-157. doi:https://doi.org/10.33394/jk.v4i2.1123

Slamento. (2003). Belajar dan Faktor yang Mempengaruhinya. Jakarta: Rieneka Cipta. 
Suarni, G., Rizka, M., \& Zinnurain, Z. (2021). Analisis Pengaruh Penerapan Model Pembelajaran Sains Teknologi Masyarakat Terhadap Hasil Belajar Siswa. Jurnal Paedagogy, 8(1), 31-38. doi:https://doi.org/10.33394/jp.v8i1.3226

Taqiya, T., Sugiyono, T., \& Nugroho, A. (2021). Peningkatan Aktivitas dan Hasil Belajar Siswa pada Tema 8 Peristiwa Alam melalui Model Kooperatif Tipe STAD di Masa Pandemi Covid-19. Jurnal Paedagogy, 8(3), 369-376. doi:https://doi.org/10.33394/jp.v8i3.3892

Wirejati, W. (2019). Peningkatan Mutu Hasil Belajar Siswa Kelas IX.A SMPN 7 Pujut pada Materi Sistem Ekskresi Melalui Pembelajaran Kooperatif Tipe Student Teams Achievement Divisions. Jurnal Paedagogy, 6(2), 59-65. doi:https://doi.org/10.33394/jp.v6i2.2532

Yuliati, G. (2018). Peningkatan Hasil Belajar Matematika Siswa Kelas XI IPA 3 SMA Negeri 1 Batukliang Melalui Penggunaan Model Pembelajaran Student Teams Achievement Division. Jurnal Kependidikan: Jurnal Hasil Penelitian dan Kajian Kepustakaan di Bidang Pendidikan, Pengajaran dan Pembelajaran, 4(1), 31-40. doi:https://doi.org/10.33394/jk.v4i1.899 